\section{Acceptance and Commitment Therapy on Depression of Pulmonary Tuberculosis Patient: An Intervention Based on the Health Belief Model}

Indonesian Nursing Journal of Education and Clinic (INJEC)

I07-II5

Volume 5, Issue 2, December 2020

DOI: 10.24990/injec.v5i2.290

injec.aipni-ainec.org/index.php/INJEC/index

Received : 2020-05-08

Accepted : 2020-05-28

The Association of Indonesian Nurse

Education Center (AINEC)

\author{
Gevi Melliya Sari' ${ }^{1}$, Muhammad Amin² $^{\mathbb{D}}$, Laily Hidayati' ${ }^{1}$
}

\begin{abstract}
Introduction: Depression is a psychological disorder often experienced by patients undergoing tuberculosis treatment. The purpose of this study was to determine the effect of acceptance and commitment therapy based on the health belief model on the depression of pulmonary tuberculosis patients.

Methods: This research used a quantitative quasi-experiment design with pre-posttest control group design. There were 56 respondents in this study selected using consecutive sampling among the Primary Healthcare Center in Sidoarjo district. The independent variables were acceptance and commitment therapy based on the health belief model. The dependent variable was depression. Measurement of depression used the Beck Depression inventory II questionnaire. Analysis of the data in this study used the Wilcoxon Signed Rank Test and Mann-Whitney $U$ Test.

Results: The results showed that the treatment group $p=0.000(p<0.05)$ and control group $p=0.000$ $(p<0.05)$, but the delta of the treatment group higher than the control group (delta: -9.79$)$. There were differences in depression values obtained between the treatment group and the control group $p=0.00 \mathrm{I}$ $(p<0.05)$.

Conclusion: Acceptance and commitment therapy based on the health belief model given four sessions for 30-45 minutes each session can lower depression level in pulmonary tuberculosis patients rather than a single intervention of health education. This intervention can be used by nurses to help pulmonary tuberculosis patients overcome psychological problems during treatment.
\end{abstract}

\title{
Keywords
}

acceptance and commitment therapy; depression; health belief model; pulmonary tuberculosis

\section{INTRODUCTION}

Tuberculosis (TB) is a chronic disease with a minimum treatment time of six (6) months. This disease is one of the ten highest causes of death in the world (World Health Organization, 2019). Tuberculosis is caused by the bacterium Mycobacterium Tuberculosis, which can attack the pulmonary or other organs (Extra Pulmonary) (World Health Organization, 2019). Tuberculosis is caused by the bacterium Mycobacterium Tuberculosis, which can attack the pulmonary or other organs (Extra Pulmonary). Patients must take

\footnotetext{
I Faculty of Nursing, Universitas Airlangga, Surabaya, Indonesia

${ }^{2}$ Hospital of Universitas Airlangga
}

\section{Corresponding Author:}

Laily Hidayati, Faculty of Nursing, Universitas Airlangga, Surabaya, Indonesia

Universitas Airlangga Kampus C, Jl. Mulyorejo, Mulyorejo, Surabaya, Kota SBY, Jawa Timur 60II5

Email: laily-h@fkp.unair.ac.id 
medication regularly because the healing of this disease depends on patient compliance in the following treatment. Long treatment time and large amounts of drugs increase psychological problems in patients. The presence of chronic diseases also increases the high risk of psychological issues (Madva et al., 2019). Depression is a psychological problem that often occurs in patients with pulmonary tuberculosis (Amreen \& Rizvi Nadeem, 2016). The prevalence of depression in patients with tuberculosis is reported to be three times higher than in patients without tuberculosis (Tilahun, Awoke, Geda, \& Mesfin, 2018). Some research on the self-concept of TB patients revealed that patients felt bored, ashamed, lacked self-confidence, withdrew from their environment, and were afraid of being shunned by friends (Nurhidayati, Sulistyowati, \& Dewi, 2019). Depression is a mood disorder. People who experience depression are characterized by the appearance of several symptoms, such as easy to despair, often blame themselves, sadness, low self-esteem, eating disorders, and sleep disorders to result in loss of interest in everything. Psychological interventions are needed to help patients improve adherence to treatment, but there is little psychological intervention that can be applied to tuberculosis patients. The acceptance and commitment therapy based on the health belief model is one of the psychological interventions that can help reduce depression in chronic diseases, but its effect on pulmonary tuberculosis patients still cannot be explained. The researchers wanted to find out the effect of the acceptance and commitment therapy based on the health belief model intervention on depression in pulmonary tuberculosis patients.

The prevalence of tuberculosis is increasing every year. In 2017 it was 6.4 million increasing to 7.0 million in 2018 (World Health Organization, 2019). Since 2013, Indonesia has ranked third among countries with the highest prevalence of tuberculosis cases, with 331,703 in 2013 increasing to 563,879 in 2018 ,an increase of $70 \%$, and $28 \%$ between 2017 and 2018 of 121,707 cases (World Health Organization, 2019). The prevalence of depression in tuberculosis patients is $38.1 \%$ (Lee, Tung, Chen, \& Fu, 2017). In the Tola study, the prevalence of depression in tuberculosis patients was 44-67.6\% (Tola et al., 2015). The prevalence of depression in
Indonesia, according to Suryani et al. (2016), with the prevalence of psychological disorders measured by the DASS questionnaire (Depression, Anxiety, Stress Scale), found $64.9 \%$ of patients experiencing complications at mild levels and $35.1 \%$ at moderate levels. Depression in pulmonary tuberculosis patients can increase the risk of treatment patients dropping out. The greater risk of the occurrence of depression can change the patient's health behavior for the worse, thereby increasing the risk of drug withdrawal, drug resistance, and increasing mortality in patients (Dasa et al., 2019).

Acceptance and commitment therapy intervention is a cognitive therapy which helps the individual to be open, aware, play an active role, and develop psychological flexibility. Psychological flexibility is the ability of individuals to consciously accept an event to change and survive in the situation based on the values they believe (Hayes, 2008). The health belief model theory is a theory of behavior change and psychological models can realize health behavior that comes from the perceptions and beliefs that exist in patients against the disease they experience (Priyoto, 2014). The acceptance and commitment therapy, based on the health belief model, is expected to help overcome the problem of depression in pulmonary tuberculosis patients. This study aims to explain the effect of acceptance and commitment on the depression of pulmonary tuberculosis patients based on the health belief model.

\section{MATERIALS AND METHODS}

This research used a quasi-experiment design with a pre-posttest control group design. The study was conducted from December 2019 to February 2020. The location in this study was in the Primary Health Care in Sidoarjo district. The number of samples in this study was 56 respondents obtained by consecutive sampling for one month. Respondents were divided into two groups, 28 in treatment group, and 28 control group respondents. Inclusion criteria in this study were patients with pulmonary tuberculosis in the intensive phase (I-2 months), do not have a history of DM and HIV, and cooperative. The exclusion criterion in this study was respondents with a history of 
previous mental disorders. The independent variables were acceptance and commitment therapy based on the health belief model. The dependent variable was depression.

Data demographics consist of gender, age, religion, level of education, occupation, marital status, and side effect. Side effects were mild and severe; the mild side effect was no appetite, nausea, stomach ache, joint pain, tingling until the burning sensation in the legs, and reddish color in urine. The severe side effect was itching and redness, deaf, balance disorders, jaundice without other causes, confusing and vomiting (onset of jaundice due to drugs), purpura, and shock (Kepmenkes, 2009). Measurement of respondent's depression level was done using the Beck Depression Inventory-II (BDI II) questionnaire. This questionnaire can be used on patients older than thirteen years (Segal, 2010). The results of the validity and reliability test of the BDI II questionnaire by researchers were 0.985 and $0.98 \mathrm{I}$, respectively. The category score of depression used the Beck Depression Inventory-II questionnaire where a score range 0 - I3 was the minimum level, mild depression was a score range 14-19, moderate depression was a score range 20-28, and severe depression was a score range 29-63(Roelofs et al., 20I3).

After obtaining a research permit from the Sidoarjo Health Office and the approval of the head of the community health center, the researchers screened respondents based on inclusion criteria. In tuberculosis patients undergoing treatment of fewer than two months, researchers gave a depression questionnaire. Respondents who experienced mild and moderate depression were given informed consent and an explanation of the intervention to be given and how long the patient will be given the intervention. In patients who refused to enter the exclusion criteria, this research may be carried out by registered nurses. In the control group after pretest-posttest given in the next four weeks, posttest measurements were performed at week four of treatment. In the treatment group, acceptance and commitment therapy based on the health belief model was given for four sessions. Each session consisted of 30-45 minutes given by researchers. The treatment was given by direct counseling.

The first session was about acceptance, cognitive defusion, and belief in patients about treatment. In this session, the researcher identified the behavior, experience, or feeling that was disturbed during the treatment the patient was experiencing, identifying the patient's acceptance, and the patient's health beliefs. The second was about the present moment and patient values. In this session, the researcher identified values selected based on patient experience. The third session was about committed action and self as context. In this session, the researcher practiced accepting events related to illness and treatment based on the value chosen by the patient. The fourth session was about commitment to treatment. This session was about fostering a patient's commitment to medication adherence. Intervention for each session was given once a week for each session. In the control group, respondents were given standard interventions from the Primary Health Care center, namely health education regarding tuberculosis as well as the rules in taking medicine and the importance of preventing transmission by using masks.

Descriptive analysis was used for respondent characteristics. The homogeneity test uses Levene's tests with a significance level of $p>0.05$. The statistical test used the Wilcoxon Signed Rank Test with a significance level of $p<0.05$ to analyze the depression value before and after. Then, to analyze postdepression value between the treatment group and the control group, the Mann Whitney $U$ test was used with a significance level of $p<$ 0.05. The Faculty of Nursing Universitas Airlangga gave ethical clearance for this study with number 1838-KEPK on November 28, 2019. 
Table I. Characteristics of Respondents

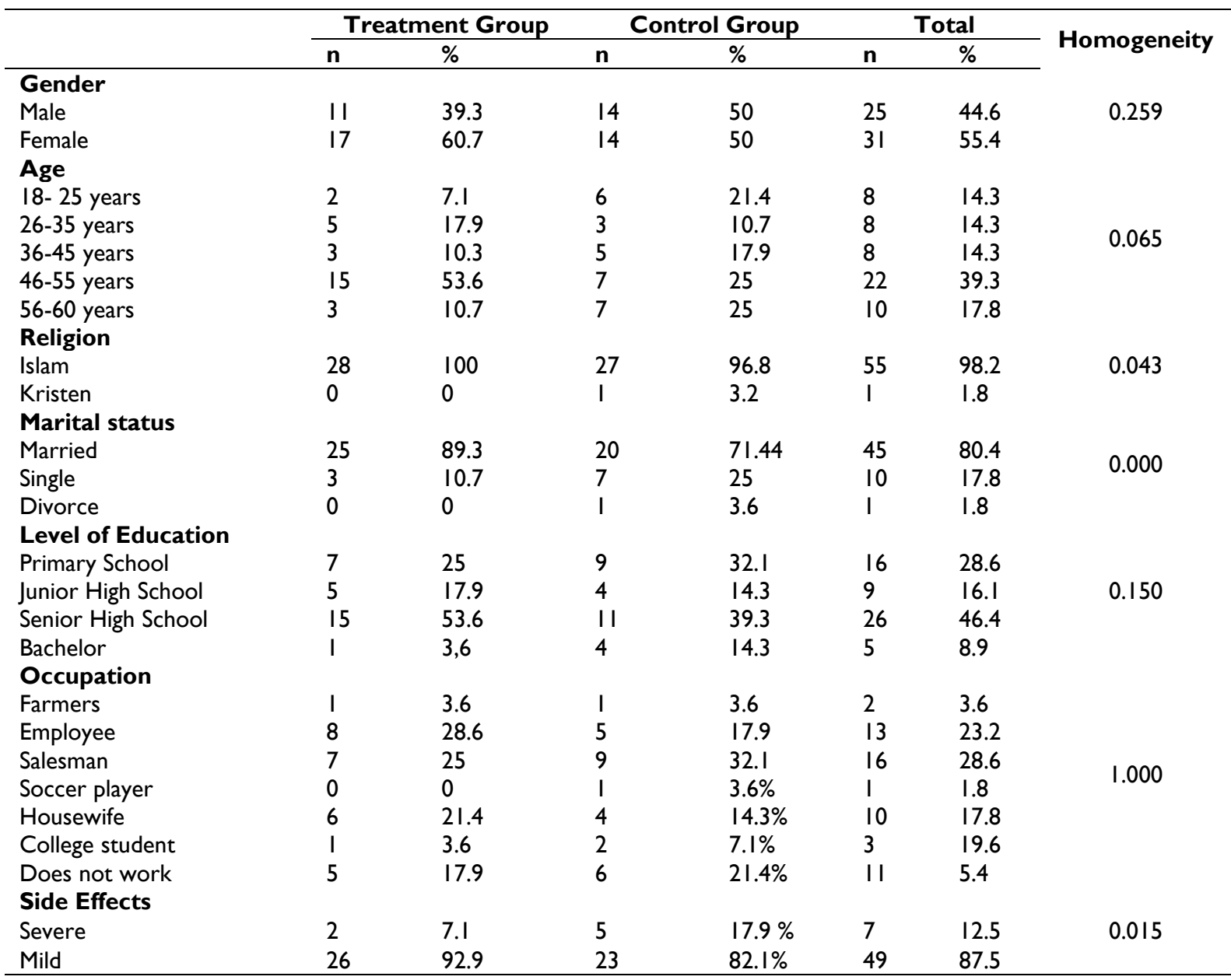

Table 2. Effect of Acceptance and Commitment Therapy Based on Health Belief Model on Depression of Pulmonary Tuberculosis in the Intervention and Control Groups

\begin{tabular}{|c|c|c|c|c|c|c|c|c|c|}
\hline \multirow{3}{*}{ Variable } & \multirow{3}{*}{ Level } & \multicolumn{4}{|c|}{ Treatment Group } & \multicolumn{4}{|c|}{ Control Group } \\
\hline & & \multicolumn{2}{|c|}{ Pretest } & \multicolumn{2}{|c|}{ Posttest } & \multicolumn{2}{|c|}{ Pretest } & \multicolumn{2}{|c|}{ Posttest } \\
\hline & & $n$ & $\%$ & $\mathbf{n}$ & $\%$ & $n$ & $\%$ & $n$ & $\%$ \\
\hline \multirow{3}{*}{ Depression } & $\begin{array}{c}0-13 \\
\text { Minimum }\end{array}$ & 0 & 0 & 28 & 100 & 0 & 0 & 25 & 89.3 \\
\hline & $\begin{array}{l}14-19 \\
\text { Mild }\end{array}$ & 25 & 89.3 & 0 & 0 & 26 & 92.9 & 3 & 10.7 \\
\hline & $\begin{array}{c}20-28 \\
\text { Moderate }\end{array}$ & 3 & 10.7 & 0 & 0 & 2 & 7.1 & 0 & 0 \\
\hline Total & & 28 & 100 & 28 & 100 & 28 & 100 & 28 & 100 \\
\hline
\end{tabular}

Table 3. Effect of Acceptance and Commitment Therapy Based on Health Belief Model on Depression of Pulmonary Tuberculosis Patients $(n=56)$

\begin{tabular}{ccccccccc}
\hline \multirow{2}{*}{ Variable } & Group & $\begin{array}{c}\text { Pre-Test } \\
\text { (Mean } \pm \text { SD) }\end{array}$ & $\begin{array}{c}\text { Min- } \\
\text { Max }\end{array}$ & $\begin{array}{c}\text { Post-Test } \\
(\text { Mean } \pm \text { SD) }\end{array}$ & $\begin{array}{c}\text { Min- } \\
\text { Max }\end{array}$ & $\begin{array}{c}\text { Delta } \\
(\boldsymbol{\Delta})\end{array}$ & $\mathbf{p}^{*}$ & $\mathbf{p}^{* *}$ \\
\hline \multirow{2}{*}{ Depression } & Treatment & $15.75 \pm 2.137$ & $14-22$ & $5.96 \pm 1.453$ & $4-10$ & -9.79 & 0.000 & 0.001 \\
& Control & $15.21 \pm 2.079$ & $14-20$ & $7.86 \pm 3.052$ & $5-17$ & -7.35 & 0.000 & 0.00 \\
\hline
\end{tabular}

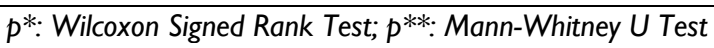




\section{RESULTS}

The most gender in this study was female with $3 \mathrm{I}$ respondents (55.4\%). On the gender characteristics of the homogeneity test, results were significant with $p=0.259(p>0.05)$. The majority of the age was $46-55$ years, as many as 23 respondents (37.1\%). Homogeneity test on the age characteristics was significant with $P=0.065 \quad(p>0.05)$. Most of the respondents' religion was Islam. Homogeneity test results were not significant with $P=0.043 \quad(P<0.05)$. Regarding marital status, most of the respondents were married, 45 respondents (80.4\%). Homogeneity test results are not significant with a value of $p$ $=0,000 \quad(p<0.05)$. The majority of respondents' education was high school, as many as 26 respondents (46.4\%). There were significant homogeneity test results with a value of $p=0.150(p>0.05)$. The most occupation in the treatment group was salesmen with 16 respondents (28.6\%). Homogeneity test results were significant with $p=1,000(p>0.05)$. Regarding the side effects of the drug in both groups, they experienced mild side effects in 49 respondents (87.5\%). Homogeneity test results show that the characteristics of side effects are not significant with $p=0.015$ ( $p$ $<0.05$ ).

Table 2 shows depression in the treatment group, where there were 25 respondents $(89.3 \%)$ in level mild depression, and three respondents in level moderate $(10.7 \%)$. After intervention of acceptance and commitment therapy based on the health belief model for four sessions in four weeks, there were all respondents $(100 \%)$ in minimum level. In the control group data pretest, there were 26 respondents (92.9\%). After four weeks, there were 25 respondents $(89.3 \%)$ in minimum level and three respondents (10.7\%) still in mild depression level.

Table 3 shows the treatment group obtained the mean value of the pretest of the depression $15.75 \pm 2.137$. The mean value of depression posttest was $5.96 \pm 1.453$, and the delta value was $\mathbf{- 9 . 7 9}$. Wilcoxon Signed Rank
Test results in the treatment group were $p=0.000(p<0.05)$. The control group obtained the mean pretest I5.2I \pm 2.079. After four weeks, the mean posttest value was -7.35 . Wilcoxon Signed Rank Test results in the control group obtained $p=0.000 \quad(p<0.05)$. Intervention in the control group results were significant, but the values of the delta of acceptance and commitment therapy were higher than the control group. Data posttest depression analysis was performed used the Mann-Whitney $U$ Test, the measurement showing differences in intergroup interventions obtained $p=0.000, p<0.05$, which means the data were significant, and the alternative hypothesis was accepted. There was an influence of intervention using acceptance and commitment therapy in lowering depression of pulmonary tuberculosis patients based on the health belief model compared to a single health education intervention.

\section{DISCUSSIONS}

Acceptance and commitment therapy lowers depression of pulmonary tuberculosis patients. The mean value after giving acceptance and commitment therapy based on the health belief model was higher than a single intervention. In depression, patients experience sleep disorders, eating disorders, despair, decreased mood, loss of interest, decreased motivation, to the point of suicide.

The results showed that more female patients with pulmonary tuberculosis were depressed than male patients, which was in line with Rizvi, (2016), women are more prone to experience depression than men (Kehbila et al., 2016). Female patients have a higher risk of experiencing depression in line with research by $\mathrm{Gul}$ and $\mathrm{Al},(2017)$. In the data about the most vulnerable age, this was 46-55 years in line with research showing these years were at high risk of experiencing depression because this vulnerable age is included in the productive age where a person should be able to do many things (Wang et al., 20I8). In line with the study of Gul and Al, (2017) about characteristics of age in depression among tuberculosis cases, the majority was more than 15 years and less than 59 years. Regarding the marital status of pulmonary tuberculosis patients, those who were married were more depressed. This is in line with research by Mirza and Jenkins, (2004) 
who found marital status can increase the risk of depression due to problems in the household and pressure from in-laws. In occupational characteristics, one's income was related to the prevalence of depression in tuberculosis. This is in line with research (Dasa et al., 2019) finding that low income increases psychological pressure due to inability to meet the needs of the patient's own life and that of their family. Regarding drug side effects, there were respondents who experienced severe side effects of drugs. Drug side effects increase the prevalence of depression in pulmonary tuberculosis patients. This is in line with research (Dasa et al., 2019) finding that early diagnosis of tuberculosis and drug side effects increase the prevalence of depression in patients with pulmonary tuberculosis. Depression in tuberculosis patients was more common in patients with intensive phases. In line with the study by Tola et al., (20I5), conducted in Ethiopia, patients who experienced psychological pressure in the intensive phase were $67.6 \%$ and the advanced phase was $32.4 \%$.

In the treatment group, respondents were given acceptance and commitment therapy based on the health belief model. Such interventions stimulate the perceptions of the respondents. The development of psychological flexibility conducted by researchers to the respondent helped respondents to increase their ability to consciously change in their lives and accept the change based on the values believed by respondents, despite many obstacles in life (Hayes, Luoma, Bond, Masuda, \& Lillis, 2006). In the acceptance and commitment therapy intervention based on the health belief model, depression is an emotion related to the individual's past, such as death or loss of something and the process of adjusting to stressful life events (National Institute of Mental Health, 2016). In patients with pulmonary tuberculosis, the respondent feels they have lost their previous health status. Each session on this intervention stimulates the individual to do things such as making decisions following treatment programs and adaptive coping management according to the value of his belief. With full awareness of an event, it is hoped that individuals can leave their thoughts and feelings openly and allow those that come and go as they are unable to control and stimulate individual self-acceptance (Teasdale et al., 2000). The experience or something that is felt to be disturbing by the individual is expected not to disturb the thoughts and feelings of the respondent. Then, regarding the values that individuals believe, these can maintain and enhance their positive behavior (McCracken \& Vowles, 2014). In this research, respondents had a value that they wanted to make their family happy and to get well soon and be able to interact with their family without fear of spreading the disease. They tried to accept that there are germs in their body that make them sick, so they were stimulated to not easily give up with the situation they were currently experiencing. Individual awareness and self-acceptance of what they are experiencing can reduce negative thoughts and stimulate respondent behavior that leads to positive actions and reduces individual depression. In line with research (A-Tjak, Morina, Topper, \& Emmelkamp, 2018), Acceptance and commitment therapy can reduce depression in patients with major depression. Also, as supported the research by Saedy, Kooshki, Firouzabadi, and Emamipour, (2015), acceptance and commitment therapy can reduce depression in patients with opioid dependence. In line with research by Walser et al. (20I5), acceptance and commitment therapy can reduce depression and suicidal ideas, while, in research by Pots et al. (2016), acceptance and commitment therapy can reduce symptoms of depression, although with a different method based on telehealth.

In the control group that was given health education regarding pulmonary tuberculosis, respondents also experienced a decrease in depression. This was in line with research by Ambaw, Mayston, Hanlon, and Alem, (2015) that knowledge and social support are associated with decreased depression. Some respondents still experience depression after being given a health education intervention and factors that influence the prevalence of depression are community isolation, low selfimage, and low self-esteem (Molla, Mekuriaw, \& Kerebih, 2019). The limitation of this study is that was no follow-up at the end of the intensive phase and the advanced phase due to differences in the final intensive phase of the respondents. Research focused on reducing the level of depression in patients so it was not 
known whether it was associated with an increase in patient adherence in undergoing treatment.

\section{CONCLUSION}

Acceptance and commitment therapy based on health belief models can help reduce depression in patients with pulmonary tuberculosis. Nurses can use this intervention in helping pulmonary tuberculosis patients overcome their psychological problems. By providing a comprehensive intervention it is hoped that it can improve the compliance of pulmonary tuberculosis patients in undergoing treatment. Acceptance and commitment therapy interventions can be given as an additional alternative to pulmonary tuberculosis patients in providing holistic interventions and are expected to help optimize treatment in such patients. Further research is expected to examine the effectiveness of interventions for acceptance and community therapy for adherence in patients with pulmonary tuberculosis in undergoing treatment.

\section{Acknowledgement}

We would like to thank the participants who have helped in this research and the research sites that have facilitated this research.

\section{Conflict of Interest}

All the authors have no conflict of interest related to the study.

\section{REFERENCES}

A-Tjak, J. G. L., Morina, N., Topper, M., \& Emmelkamp, P. M. G. (2018). A Randomized Controlled Trial in Routine Clinical Practice Comparing Acceptance and Commitment Therapy with Cognitive Behavioral Therapy for the Treatment of Major Depressive Disorder. Psychotherapy and Psychosomatics, 87(3), 154-163. https://doi.org// 0.1 I59/000486807

Ambaw, F., Mayston, R., Hanlon, C., \& Alem, A.
(2015). Depression Among Patients with Tuberculosis: Determinants, Course and Impact on Pathways to Care and Treatment Outcomes in a Primary Care Setting in Southern Ethiopia - A study Protocol. BMJ Open, 5(7), I-10. https://doi.org/I0.I I 36/bmjopen-20I5007653

Amreen and Rizvi Nadeem. (20I6). Frequency of Depression and Anxiety among Tuberculosis Patients. Journal of Tuberculosis Research, 4, 183-190. https://doi.org//0.4236/jtr.2016.4402I

Dasa, T. T., Roba, A. A., Weldegebreal, F., Mesfin, F., Asfaw, A., Mitiku, H., ... Tesfaye, E. (20/9). Prevalence and Associated Factors of Depression Among Tuberculosis Patients in Eastern Ethiopia. BMC Psychiatry, 19(1), I-8. https://doi.org/I 0.1 I86/s I 2888-0 I 9-20426

Gul E, \& et al. (20I7). Frequency of Depression in Patients Suffering from Pulmonary Tuberculosis. Pakistan Journal of Chest Medicine, 23(I), 03-07. Retrieved from https://pdfs.semanticscholar.org/8bb7/002 987/6bdc7e4be7fdc23406e9044f8ddc5.p df

Hayes, S. C. (2008). Acceptance and Commitment: Implication for Prevention Science. National Instituties of Health, 23(I), I-7. https://doi.org//0.1038/jid.20I4.37|

Hayes, S. C., Luoma, J. B., Bond, F. W., Masuda, A., \& Lillis, J. (2006). Acceptance and Commitment Therapy: Model, processes and outcomes. Behaviour Research and Therapy, 44(I), I-25. https://doi.org// 0.1016/j.brat.2005.06.006

Kehbila, J., Ekabe, C. J., Aminde, L. N., Noubiap, J. J. N., Fon, P. N., \& Monekosso, G. L. (2016). Prevalence and Correlates of Depressive Symptoms in Adult Patients with Pulmonary Tuberculosis in the Southwest Region of Cameroon. Infectious Diseases of Poverty, 5(I), I-8. https://doi.org//0.1 I86/s40249-016-0I456

Kepmenkes. (2009). Pedoman Penganggulangan Tuberkulosis. Keputusan Menteri Kesehatan Republik Indonesia (Vol. 19). Retrieved from

https://www.persi.or.id/images/regulasi/ke pmenkes/kmk3642009.pdf

Lee, L. Y., Tung, H. H., Chen, S. C., \& Fu, C. H. 
(2017). Perceived Stigma and Depression in Initially Diagnosed Pulmonary Tuberculosis Patients. Journal of Clinical Nursing. https://doi.org/ I 0. I I I I/jocn. I 3837

Madva, E. N., Gomez-bernal, F., Millstein, R. A., Celano, C. M., Park, E. R., Ph, D., ... Huffman, J. C. (2019). Magnitude and Sources of Distress in Mid-Life Adults With Chronic Medical Illness: An Exploratory Mixed-Methods Analysis. Psychol Health Med, 23(5), 555-566. https://doi.org// 0.1080/13548506.2017.13 84554.Magnitude

McCracken, L. M., \& Vowles, K. E. (20I4). Acceptance and Commitment Therapy and Mindfulness for Chronic Pain: Model, Process, and Progress. American Psychologist, 69(2), 178-187. https://doi.org//0.1037/a0035623

Mirza, I., \& Jenkins, R. (2004). Risk Factors, Prevalence, and Treatment of Anxiety and Depressive Disorders in Pakistan: Systematic Review. British Medical Journal, 328(7443), 794-797. https://doi.org/ I 0.1 I 36/bmj.328.7443.794

Molla, A., Mekuriaw, B., \& Kerebih, H. (2019). Depression and Associated Factors Among Patients With Tuberculosis in Ethiopia: A Cross-Sectional Study. Neuropsychiatric Disease and Treatment, 15, |887-|893. https://doi.org/ 0.2 | 47/NDT.S20836 |

National Institute of Mental Health. (2016). Depression Basics. National Institutes of Health. https://doi.org/10.1039/c3cc46800c

Nurhidayati, I., Sulistyowati, A. D., \& Dewi, A. Y. K. S. (20/9). Health Belief Penderita Tuberkulosis Paru Relaps di Balai Kesehatan Masyarakat (BALKESMAS) Wilayah Klaten:Studi Fenomenologi. Jurnal Keperawatan Dan Kesehatan Masyarakat Cendekia Utama, 8(I), 17. https://doi.org//0.3 I596/jcu.v8il.302

Pots, W. T. M., Fledderus, M., Meulenbeek, P. A. M., Ten Klooster, P. M., Schreurs, K. M. G., \& Bohlmeijer, E. T. (2016). Acceptance and Commitment Therapy as a WebBased Intervention for Depressive Symptoms: Randomised Controlled Trial. British Journal of Psychiatry, 208(I), 69-77. https://doi.org/ I0.I I 92/bjp.bp.I I 4. 146068

Priyoto. (20l4). Teori Sikap dan Perilaku
Kesehatan. Yogyakarta: Nuha Medika.

Roelofs, J., Van Breukelen, G., De Graaf, L. E., Beck, A. T., Arntz, A., \& Huibers, M. J. H. (20I3). Norms for the Beck Depression Inventory (BDI-II) in a Large Dutch Community Sample. Journal of Psychopathology and Behavioral Assessment, 35(I), 93-98. https://doi.org// 0.1007/s 10862-012-93092

Saedy, M., Kooshki, S., Firouzabadi, M. J., Emamipour, S., \& Rezaei Ardani, A. (2015). Effectiveness of AcceptanceCommitment Therapy on Anxiety and Depression among Patients on Methadone Treatment: A Pilot Study. Iranian Journal of Psychiatry and Behavioral Sciences, $\quad 9(1), \quad$ I-7. https://doi.org// 0.58/2/ijpbs.222

Segal, D. L. (20I0). Diagnostic and Statistical Manual of Mental Disorders (DSM-IV-TR). In The Corsini Encyclopedia of Psychology. https://doi.org// 0.1002/97804704792 I6.c orpsy027I

Suryani, S., Widianti, E., Widianti, E., Hernawati, T., Hernawati, T., Sriati, A., \& Sriati, A. (2016). The Effectiveness of Psycho Education Towards Depression, Anxiety and Stress Level of Patients with Pulmonary Tuberculosis. Jurnal NERS, II (I),

128. https://doi.org/I0.20473/jn.vI Iil 20I6. 128 $-133$

Teasdale, J. D., Segal, Z. V., Williams, J. M. G., Ridgewaya, V. A., Soulsby, J. M., \& Lau, M. A. (2000). Prevention of Relapse/Recurrence in Major Depression by Mindfulness-Based Cognitive Therapy. Journal of Consulting and Clinical Psychology, 68(4), 615-623. https://doi.org// 0.1037/0022006X.68.4.615

Tilahun, H., Awoke, N., Geda, B., \& Mesfin, F. (2018). Depression and Associated Factors among Adult Inpatients at Public Hospitals of Harari Regional State, Eastern Ethiopia. Psychiatry Journal, 2018, I-6. https://doi.org/I0.1 I55/2018/6743520

Tola, H. H., Shojaeizadeh, D., Garmaroudi, G., Tol, A., Yekaninejad, M. S., Ejeta, L. T., ... Kassa, D. (2015). Psychological Distress and its Effect on Tuberculosis Treatment Outcomes in Ethiopia. Global Health Action, 8(I). https://doi.org/I 0.3402/gha.v8.29019 
Walser, R. D., Garvert, D. W., Karlin, B. E., Trockel, M., Ryu, D. M., \& Taylor, C. B. (20I5). Effectiveness of Acceptance and Commitment Therapy in Treating Depression and Suicidal Ideation in Veterans. Behaviour Research and Therapy, 74 , $25-31$. https://doi.org/I0.1016/j.brat.2015.08.012

Wang, X. B., Li, X. L., Zhang, Q., Zhang, J., Chen, H. Y., Xu, W. Y., ... Hou, G. (20I8). A Survey of Anxiety and Depressive
Symptoms in Pulmonary Tuberculosis Patients with and Without TracheobronchialTuberculosis. Frontiers in Psychiatry, 9(JUL), 1-10. https://doi.org//0.3389/fpsyt.2018.00308

World Health Organization. (2019). Global Tuberculosis Report. World Health Organization. Retrieved from https://apps.who.int/iris/handle// 0665/329 368. 